\title{
ARTICLES \\ New vulture censuses in the Montejo Raptor Refuge, Spain
}

Fidel José Fernández y Fernández-Arroyo

c/ Pensamiento $15,3^{\circ}$ A, 28020 Madrid, Spain

ffernan@mat.uned.es.

\section{Introduction}

The gorges of the Riaza River (Montejo Raptor Refuge and its surroundings, Segovia, Spain) are renowned as one of the most important areas in Europe for the Eurasian Griffon Gyps fulvus and the Egyptian Vulture Neophron percnopterus (Del Moral \& Martí 2001, 2002). It was one of the first protected vulture populations and it is also the best monitored colony in Spain since the Refuge was established in 1975 (Camiña 2004b, 2005; Fernández 1976, 1994b, 1999, 2004a, and references therein). The Refuge (and its surroundings) is the northernmost place in Spain where the Black Vulture Aegypius monachus has attempted recently to breed (three years; Fernández 2002, 2007b), and where the Rüppell's Griffon Gyps rueppellii has been sighted seven times (Camiña 2003; De Juana 2006; De la Puente et al. 2007; Fernández 1998b, 2002, 2005b; Forsman 2005; Gutiérrez 2003). The Bearded Vulture Gypaetus barbatus has also been observed there (Fernández 2003c). In the Refuge and its surroundings, 325 species of vertebrates have been observed including 240 species of birds. Of these bird species, at least 127 breed in the Refuge, with another 14 species breeding in the nearby areas (Fernández 1993a, 2008b). The Refuge and its surroundings is also a key area for steppe birds (Fernández 2003b).

In Spain, the new compulsory removal of animal corpses (Camiña 2004a; González \& Moreno-Opo 2008; Suárez 2008; Tella 2006) is doubtless the main cause of the recent reduction in the number of vultures in different regions (Camiña 2007; Camiña \& López 2009; FAB 2008; Fernández 2007c, 2007d, 2009; Melero, 2007b; Pérez de Ana 2007). In recent years, a similar decline has been noted in the French Pyrenees (LPO 2008; Razin et al. 2008).

On the other hand, in the Gorges of Riaza north of Segovia Province (Spain), the present situation is characterised by problems related to public use of the new Natural Park (Fernández 2003a, 2005c; Gomis 2005, 2006; Hernando et al. 2005; Ramos 2003) and other problems in nearby areas such as poison (Fernández 
2007b, 2008a; Suárez 2007), electrocution and collision with power lines (Cobo 1992; Doval et al. 2005; Fernández 2007b; Melero 2005; WWF/Adena 2007), accidents related to windfarms, and other threats (Fernández 2006).

Most of these problems also exist in many other regions (Raptor Research Foundation, 2007). In the past, the intense monitoring carried out in the Montejo Refuge has enabled general trends to be followed for vultures (Arroyo et al. 1990; Camiña \& López 2009; Fernández 1981, 1983, 1984; Perea et al. 1990) and other species (Arroyo et al. 1996; Fernández 1996b, 1998a; Ruiz-Olmo \& Delibes 1999). Therefore, it is especially interesting to know the evolution of this significant colony during recent years. The results of all the censuses carried out by the author in the Refuge between 1975 and 2003, along with the results of the autumn censuses, conducted between 1983 and 2003, have already been published (Fernández 1976, 1994b, 1996a, 1999, 2004a). This paper presents the results of the censuses carried out by the author between 2004 and 2008, the results of the autumn censuses in the same period and some new information on other vultures in the area. Some of these data have appeared (except for the final two years) in Fernández (2004b, 2005a, 2006, 2007b) and Prieto et al. (2007, 2008). The aims of the vulture monitoring and work at the Montejo Raptor Refuge have been discussed previously (Fernández 1999).

\section{Methods}

As described in Fernández (1999), the raptor censuses carried out in the Montejo Raptor Refuge (and its surroundings), have been mainly three types:

1. Every year since 1975, I have surveyed the chicks of the Eurasian Griffons and the Egyptian Vultures, and other raptors. Every survey has two components. Firstly, each year, for more or less 40-45 whole days between May and June, a short while before the first Eurasian Griffon chicks begin to fledge (Fernández 1996a), I have surveyed all the cliffs, to get an exact count of the number of Eurasian Griffon chicks, and also the occupied Egyptian Vulture nests. Secondly, between July and August, shortly before the first Egyptian Vulture chicks begin to fledge (Fernández 1994b), I have surveyed the whole region again, to count exactly how many Egyptian Vulture chicks were present, and also to determine the number of later-hatched Eurasian Griffon chicks and to determine how many vultures have survived until this time. If there were some very late Egyptian Vulture (or Eurasian Griffon) chicks, these nests were again visited later in the season.

2. Since 1983, autumn censuses have been carried out by a total of 627 ornithologists until 2011, mainly from different regions of the Iberian Peninsula (Fernández 1997; Martínez \& Cobo 1993). All the vultures and other birds of prey present in the area 
have been simultaneously counted, during one single sunset and sunrise during mid-November. The largest number of participants was 102 in 2004. I coordinated all the earlier censuses, but during more recent years (since 1994) this has been done by Juan Prieto Martín.

3. There have been complete breeding surveys of the area since 1984 of the Eurasian Griffons and since 1982/83 of the Egyptian Vultures and other raptors. They have been carried out by many ornithologists (see Fernández 1999, 2007b and the authors and references cited therein).

Here, we present a numerical comparison, checked every year, between the three different kinds of vultures censuses carried out in this region (see
Fernández 1997, 2007b; Melero 2007a, 2007b; Prieto et al. 2007, 2008).

The time spent by the author in the area, mainly for carrying out the censuses, exceeds 25,326 hours during 34 years (1975-2008).

\section{Results}

Eurasian Griffon Gyps fulvus

1. Autumn censuses.

The results of the autumn censuses, on the minimum number of Eurasian Griffons recorded during the last five years, can be seen in Table 1. The 2003 provisional data published in Fernández (2004a) has been confirmed, except for the number of participants, which was 81 instead of 80 . A total of 576 ornithologists participated in the autumn censuses between 1983 and 2008.

Table 1. Minimum number of Eurasian Griffons recorded in the Gorges of Riaza during the autumn, from 2004 to 2008 . In the second column is the number of participants that assisted with each survey. Data from the previous surveys (19832003) have been published in Fernández (1999, 2004a).

\begin{tabular}{|l|l|l|}
\hline Data of survey & No. of participants & No. of Eurasian Griffons \\
\hline $13 / 14$ Nov 2004 & 102 & $1,117-1,122$ \\
\hline $12 / 13$ Nov 2005 & 74 & $955-978$ \\
\hline $11 / 12$ Nov 2006 & 88 & $745-750$ \\
\hline $10 / 11$ Nov 2007 & 67 & $773-777$ \\
\hline $8 / 9$ Nov 2008 & 53 & 753 \\
\hline
\end{tabular}


All the main census locations (40-50) have been well covered every year. Some participants may be in locations with almost no vultures, watching other species, or helping. It is for this reason that the number of participants has been sufficient every year, and there is no indication that the number of observers affects the number of counted vultures (Fernández 1999, 2004a; Prieto et al. 2007, 2008).

2. Breeding censuses.

The results of the fledgling chicks censuses carried out by the author between 2004 and 2008 are given in Table 2. The data of the preceding 29 years (1975-2003) have been published (Fernández 1976, 1996a, 1999, 2004a).

Table 2. Number of Eurasian Griffon nests where breeding was successful between 2004 and 2008. Refuge: inside the Refuge; Park: inside the present Natural Park; Out: outside the present Natural Park; Total: in all the Gorges of Riaza.

\begin{tabular}{|l|l|l|l|l|}
\hline Year & Refuge & Park & Out & Total \\
\hline 2004 & 134 & 179 & 20 & 199 \\
\hline 2005 & 106 & 136 & 15 & 151 \\
\hline 2006 & 116 & 160 & 17 & 177 \\
\hline 2007 & 75 & 109 & 22 & 131 \\
\hline 2008 & 77 & 105 & 26 & 131 \\
\hline
\end{tabular}

Between 1977 and 2008 inclusive, at least 4,132 Eurasian Griffon chicks reached fledging age in the Gorges of Riaza in 722 different nests (494 within and 228 outside the Refuge).

Between 2002 and 2008, the proportion of Eurasian Griffon chicks that died or went missing from their nests before they could fly, between May and July, has increased (Table 3). This phenomenon has happened before (Fernández 1996a, 1999;
Martínez \& Fernández 1992), but not very often (Fernández 2004a).

For more information on the annual censuses on breeding pairs, see for example Blanco et al. (1997), Cobo \& Suárez (2000), Linares (2008), Martínez (1985), Martínez \& Cobo (1993), Martínez et al. (1997, 1998), Melero (2006a, 2007a, 2007b), Melero \& Suárez (2005), Prieto et al. (2007), Suárez (2000) and references therein. 
Table 3. Proportion of Eurasian Griffon chicks dead or missing from their nests before they could fly, 2002 to 2008, Gorges of Riaza. A - total number of chicks (missing between May/June); B - chicks missing between June/July; C - proportion of chicks hatched that went missing.

\begin{tabular}{|l|l|l|l|}
\hline Year & $\begin{array}{l}\text { A - May/June } \\
\text { Hatched chicks (missing) }\end{array}$ & $\begin{array}{l}\text { B - June/July } \\
\text { Missing }\end{array}$ & $\begin{array}{l}\text { C - Proportion } \\
\text { missing (\%) }\end{array}$ \\
\hline 2002 & $198 \quad(9)$ & 6 & 7.6 \\
\hline 2003 & $222 \quad(9)$ & 6 & 6.8 \\
\hline 2004 & $216 \quad(17)$ & 4 & 9.7 \\
\hline 2005 & $168(17)$ & 2 & 11.3 \\
\hline 2006 & $183(6)$ & 13 & 10.4 \\
\hline 2007 & $139(8)$ & 6 & 10.1 \\
\hline 2008 & $142(11)$ & 4 & 10.6 \\
\hline
\end{tabular}

With regard to many other questions and studies about the Eurasian Griffon in the Montejo Raptor Refuge, see Fernández 1994b, 1999, 2001a, 2001 b, 2004a, 2004b, 2005a, 2006, 2007a, 2007b, 2007c, 2008a, 2008b, 2008c, 2009, and references therein.

Egyptian Vulture Neophron percnopterus The results of the censuses from 2004 to 2008 are shown in Table 4. The results of preceding censuses are already published
(Fernández 1994a, 1999, 2004a). The censuses are exact with regard to the number of chicks that fledged and the number of nests with successful breeding. Replacement clutches have been considered as being the same attempt at breeding (Fernández 1999 and references therein; Martínez \& Blanco 2002). More information can be found in Doval et al. (2005) and Fernández (2004b, 2006, 2007b). 
Table 4. Results of censuses of Egyptian Vultures in the Gorges of Riaza and in the nearby zones between 2004 and 2008. P: number of pairs present, A: attempts at breeding, S: nests with successful breeding, T: nests with two chicks which fledged, F: chicks that fledged, $N$ : minimum number of birds present, including immature birds. (In brackets: inside and outside the actual Natural Park, respectively; except in the last column, $\mathrm{N}$, which refers outside the Park only).

\begin{tabular}{|c|l|c|c|c|c|c|}
\hline Year & \multicolumn{1}{|c|}{$\mathbf{P}$} & $\mathbf{A}$ & $\mathbf{S}$ & $\mathbf{T}$ & $\mathbf{F}$ & $\mathbf{N}$ \\
\hline 2004 & $10(7+3)$ & $10(7+3)$ & $5(4+1)$ & $2(1+1)$ & $7(5+2)$ & $28-29(8)$ \\
\hline 2005 & $10-11(7-8+3)$ & $8(6+2)$ & $8(6+2)$ & $1(0+1)$ & $9(6+3)$ & $33-35(10)$ \\
\hline 2006 & $10(7+3)$ & $9-10(6-7+3)$ & $7(5+2)$ & $3(2+1)$ & $10(7+3)$ & 33 \\
\hline 2007 & $10-11(7+3-4)$ & $7(4+3)$ & $5(2+3)$ & $2(1+1)$ & $7(3+4)$ & $30-32(13)$ \\
\hline 2008 & $9-10(5-6+4)$ & $7(3+4)$ & $5(3+2)$ & $2(1+1)$ & $7(4+3)$ & $34-37(17-18)$ \\
\hline
\end{tabular}

There are 22-23 different Egyptian Vulture "territories" in the area (18-19 in the Riaza gorges, and four in nearby zones). They have never been simultaneously occupied (Fernández 1994a, 2004a). In the last two years, in spite of the great diminution of the Egyptian Vulture population in the protected area, a new territory has been established, outside the Natural Park (see Table 4).

Between 1983 and 2008, 299 Egyptian Vulture chicks have fledged within the study area: 238 in the Gorges of Riaza (183 inside and 55 outside the Refuge) and 61 in nearby areas. They have fledged in 70 different nests of which 63 were in the Gorges of Riaza (48 inside and 15 outside the Refuge) and seven were in nearby areas. There have been at least 20 other nests $(12$ inside the Refuge, six in the remainder of the Gorges of Riaza, and two more in nearby areas) in which the breeding has failed (Fernández 1994a, 1999, 2004a, 2004b, 2006, 2007b). The 1983/84/85 surveys were conducted by Mario Morales, José Luis Perea, and José Velasco (and almost all verified by the author). These 299 chicks $(238+61)$ correspond to 211 cases $(170+41)$ of successful breeding. There have been 88 nests with two fledged chicks $(68+20)$, and 123 nests with a single chick that fledged $(102+21)$. An abstract of the reproduction data during the last 23 years can be found in Table 5 . 
During the last 34 years, there are records of at least 21 dead Egyptian Vultures in the Refuge and in the nearby zones (not including several cases further away). These include 12 adults, one bird of undetermined age, one sub-adult, one immature, one second-year bird and five first-year birds. The deaths have been probably (almost certainly) caused by poison (Six adults, one bird of nondetermined age, and one sub-adult of four years), electrocutions or collisions with power lines (two adults, one immature, one second-year bird, and three first-year birds) and shooting (two adults). The other two adults and two first-year birds died from unknown causes.
Poison seems to have caused the loss of at least two breeding territories, where Egyptian Vultures have not returned to breed. Detailed information about the first 19 cases can be found in Fernández (2004b, 2006, 2007b). On the other hand, in relatively near zones we have had data about other four Egyptian Vultures dead by poison: one in the province of Burgos in 1998 and another in Soria in 2000. Two more poisoning cases were recorded further away in Palencia in 2002 (Fernández 2004b, 2006). Moreover, three or four Egyptian Vultures tagged in the Refuge have been found dead in other places (some of them poisoned) (Doval et al. 2005; Fernández 1994a, 2006, 2007b).

Table 5. Egyptian Vulture reproduction in the last 23 years. (H: Percentage of pairs which begin to breed, with regard to controlled pairs, E: percentage of pairs with successful breeding, related to pairs which begin to breed, P: productivity (number of fledgling chicks / number of controlled pairs), T: rate of flight (number of fledgling chicks / number of successful nests). (Numbers in brackets correspond to the Riaza gorges and to the nearby zones, respectively).

\begin{tabular}{|l|l|l|l|l|}
\hline & $\mathbf{1 9 8 6 - 1 9 9 5}$ & $\mathbf{1 9 9 6 - 2 0 0 5}$ & $\mathbf{1 9 8 6 - 2 0 0 5}$ & $\mathbf{1 9 8 6 - 2 0 0 8}$ \\
\hline H [Pairs - 280 & $\begin{array}{l}86.25(87.94, \\
73.68)\end{array}$ & $\begin{array}{l}89.17(86.67, \\
96.67)\end{array}$ & $\begin{array}{l}87.50(87.45, \\
87.76)\end{array}$ & $\begin{array}{l}86.73(86.00, \\
89.83)\end{array}$ \\
\hline E [Attempts - 245 & $68.12(67.74$, & $70.09(65.38$, & $\begin{array}{l}68.98(66.83, \\
79.07)\end{array}$ & $\begin{array}{l}69.40(67.44, \\
77.36)\end{array}$ \\
$(138+107)]$ & $71.43)$ & $82.75)$ & $0.85(0.81$, & $0.85(0.81$, \\
\hline P [Success - 169 & $0.84(0.85$, & $0.88(0.76$, & $1.04)$ & $1.03)$ \\
$(94+75)]$ & $0.73)$ & $1.23)$ & $1.41(1.39$, & $1.41(1.39$, \\
\hline T [Fledged - 239 & $1.43(1.43$, & $1.40(1.33$, & $1.50)$ & $1.49)$ \\
$(134+105)]$ & $1.40)$ & $1.54)$ &
\end{tabular}


Eurasian Black Vulture Aegypius monachus

In the first 34 years of the Refuge's history, between 1975 and 2008, there have been at least 413 recorded observations of the
Eurasian Black Vulture in the Gorges of Riaza and its surroundings, plus others in nearby areas. The number of the yearly observations is given in Fernández (1999, 2004b) for the first 29 years, and in Table 6 for more recent years.

Table 6. Number of observations of Eurasian Black Vulture in the Riaza gorges area from 2004 to 2008.

\begin{tabular}{|l|l|l|l|l|l|}
\hline Year & $\mathbf{2 0 0 4}$ & $\mathbf{2 0 0 5}$ & $\mathbf{2 0 0 6}$ & $\mathbf{2 0 0 7}$ & $\mathbf{2 0 0 8}$ \\
\hline Observations & 20 & 20 & 30 & 12 & 9 \\
\hline
\end{tabular}

The number of records increased greatly from 1989 until 1997. Recorded sightings remained largely similar between 1998 and 2003, and it diminished between 2004 and 2008. There have been 368 observations of single birds, 37 observations of duos, four observations of trios, three observations of four birds together, and one observation of five birds (the Black Vultures in these last four sightings were all with Eurasian Griffons). In 137 cases, the Black Vultures were perched. When the age was determined, the majority of the observed birds were immature ( 90 cases of 123), but adult birds have been observed at least 33 times. At a nearby locality, there have been observations of several Black Vultures together; up to 28 birds (with 137 Griffon Vultures and 31 other raptors) on 15 January 2006, were recorded by Jorge Remacha Lorenzo.

In a nearby area, a Black Vulture was founded dead in April 2001, probably poisoned (Fernández 2002). In March 2007, less than $50 \mathrm{~km}$ away from the Refuge, two other Black Vultures were found dead, probably poisoned (Fernández 1998c). In autumn 2006, in another area near the Refuge, a Black Vulture was found alive but unable to fly and was suspected to be poisoned. The bird recovered well in the official centre of Burgos and was released in the Refuge on $24^{\text {th }}$ November 2006 (Fernández 2007b).

\section{Rüppell's Griffon Gyps rueppellii}

There have been seven observations of Rüppell's Griffon in the Refuge. The first six sightings have been confirmed by the Rarities Committee of SEO/BirdLife. The seven records correspond to 1994 (one), 2002 (two) and 2003 (four) (Fernández 1998b, 2004b, 2005b, 2006). This is the northernmost point where this species has been observed in Spain (see Camiña 2003, De Juana 2006, De Juana \& Camiña 2001). 
Bearded Vulture Gypaetus barbatus

No sightings were recorded during 2004 to 2008 , but the species has been recorded previously (Fernández 1999, 2002).

\section{Discussion}

A comparison between the results of the three main kinds of censuses carried out in the Gorges of Riaza (see Methods) appears in Prieto et al. (2007). More details about the methods and the authors can be seen in Fernández (1976, 1981, 1983, 1994a, 1996a, 1997, 1999, 2003b, 2004a, 2006, 2007b), Martínez \& Cobo (1993), Martínez et al. (1998), Melero (2006b) and Prieto et al. 2008.

Considering the high accuracy and broad coverage of these three kinds of censuses, it is logical to consider that the number of Griffon vultures obtained in every autumn census $[\mathrm{O}(\mathrm{n})]$ must be greater than the number of breeding pairs the following year $[R(n+1)]$. This has been true until now for every case, as it can be immediately verified. Moreover, the number obtained in each autumn census, except in 2006, has also been greater than double the number of breeding pairs in the same year.
On the other hand, regarding the vultures' population, given a year $n$, the number of non-mated birds must be added to the double of the number Rt(n) of all the pairs (breeding or not). Most of the first year birds are not present in the region during the autumn census dates, according to the data obtained on ages and travels (Barrios 2007; Griesinger 1996, 1998; Prieto et al. 2007, 2008). However, some vultures from other areas that are not necessarily immature birds may be present. Mortality during the first years of life must not be underestimated. Having in mind this and other factors, it seems reasonable to expect the results from the autumn census to be less than double the number of pairs (breeding or not) in the following year, plus a number of vultures similar or slightly higher to the number $\mathrm{P}(\mathrm{n})$ of fledgling chicks in the current year.

The number of vultures obtained for every autumn census can be verified as being lower than the sum of the double of number of (breeding or not) pairs in the following year, plus the number of fledged chicks in that year multiplied by 1.2 (this last adjustment is only necessary for 2001). Therefore, every year it is verified that:

$$
2 \mathrm{R}(\mathrm{n}+1)<\mathrm{O}(\mathrm{n})<2 \mathrm{Rt}(\mathrm{n}+1)+1.2 \mathrm{P}(\mathrm{n})
$$

[In all the years, except 2001, it is also verified that $2 \mathrm{R}(\mathrm{n}+1)<\mathrm{O}(\mathrm{n})<2 \mathrm{Rt}(\mathrm{n}+1)+\mathrm{P}(\mathrm{n})]$. 
This narrow relationship, which has been checked over so many years, agrees with the previously expected results. It also confirms again the validity of the autumn and other types of censuses for knowing the vulture population and its evolution on the one hand, and for obtaining large and useful information on many other species and queries.

During the period 2004 to 2008, the changes and problems already noted by Fernández (2004a) have led to a worrying situation. The population has decreased, and in 2007 and 2008, the average dates for breeding have been the latest in the previous 34 years of continuous observation. During the 2007 breeding season there were several cases in which adult vultures left a small chick alone in the nest, even during the night. The same situation has been observed in Griffon colonies of Huesca (northern Spain - Fondo Amigos del Buitre, personal communication). This phenomenon had occurred already during the previous 32 years, but it is considered exceptional.

There are now only three vulture restaurants (Montejo, Campo and Ayllón) that continue working in the entire region, whereas previously there were 11. Moreover, the corpses available in the country have been significantly reduced, as a consequence of new EU legislation that requires the removal of fallen stock. More recently, vultures come down immediately when the Refuge guard of Montejo, Jesús Hernando, leaves carrion in the vulture restaurant of WWF Spain. They begin to feed even in his presence (Fernández 2007b, Suárez 2008). This did not happen during the previous 32 years. It appears likely that hunger must be related to the reduced count of vultures in our autumn censuses (Prieto et al. 2007).

Increased hunger can also make vultures more vulnerable to poisoning. In recent years, several poisoning cases have happened in nearby areas. The worst episode took place on $15^{\text {th }}$ March 2007, when at least 60 Griffon vultures and one Egyptian vulture came down to eat the corpse of a poisoned dog, near the village of Santa Cruz. A total of 42 Griffon Vultures died. The other 18 Griffon Vultures and one Egyptian Vulture were captured alive, recovered in an official centre of Burgos, and were released in the Refuge on $22^{\text {nd }}$ March (Fernández 2007b; Suárez 2007). Near the same village, approximately 30 Griffon Vultures ate a dead cat, in September 2008 (Fernando Miguel, pers. comm.). The Egyptian Vulture is especially vulnerable to being poisoned (Hernández \& Margalida 2009).

With regard to breeding success, published data for these colonies show that it is not high. For example, breeding success was approximately $68 \%$ in 1984 (Martínez 1985), 47 \% in 1992, 57 \% in 1997 (Martínez et al. 1998), and $62 \%$ in 1999 for the entire Segovia province (Del Moral \& Martí 2001)], and during the years 2005-2007 breeding success was between $34 \%$ and $39 \%$ (Melero et al. 2008; 
Melero 2007a, 2007b). Interestingly, the reduction in breeding success has occurred at the same time as the colony density has decreased, instead of the opposite (Fernández et al. 1998).

There are other causes of vulture mortality in addition to those mentioned already. For instance, according to the data obtained by the members of "Fondo para el Refugio" (Refuge Fund) or the guards and other members of WWF Spain, at least 296 birds of 20 species have died since 1975 due to power lines in nearby areas. 260 birds were raptors from 13 different species, of which 168 were Griffon Vultures and seven were Egyptian Vultures (Fernández 2007b, and unpublished data). Part of these power lines has been modified because of these deaths, but the problem has not been completely solved (Cobo 1992, Fernández 2006, Melero 2005, Melero et al. 2007, WWF/Adena 2007).

Deaths of vultures and other raptors caused by poisoning, illegal hunting and other reasons have been reviewed elsewhere (Fernández 1999, 2002, 2004a, 2004b, 2006, 2007b). Since 2004, a new problem has arisen, which is caused by the windfarms in the nearby zones (Camiña \& López 2009).

The impact of human disturbance cannot be underestimated (Fernández 1993b, López 1990, Zuberogoitia 2009). In particular, some cliffs used by vultures for breeding receive many visitors in their upper parts. For example, on the cliffs of La Calderona, La Hocecilla and La Catedral all, or almost all, the vulture nests have failed in the four years 2005 to 2008 inclusive. It is significant that the Natural Park in the area was declared in December 2004. A similar phenomenon has happened in the south of Valdecasuar ravine, confirming previous warnings (Fernández 2006, pp. 217-219). The decrease in the number of vultures is also significant on the famous rock of Peña Portillo (15 fledgling Griffon vulture chicks in 2006, 4 in 2007 and 2 in 2008). Moreover, nesting of Griffon and Egyptian Vultures and other raptors is increasing in several places outside the Park, in the surrounding areas (see Tables 2 and 4).

Some eggs or chicks disappear by predation (Fernández 2002, 2004b, 2006, 2007b; Martínez \& Fernández 1992), although other causes must be taken into consideration as well (Fernández 1993b, 2007b).

On the other hand, the results of the autumn censuses are especially interesting (see Table 1; and Fernández 1999, 2004a). The concordance between the first two of them (1983 and 1984) and the previously published data (Fernández 1981, 1983) show once more the usefulness of these works (see Prieto et al. 2007, 2008). This is also indicated by the close relationship that exists between these censuses and the censuses of pairs and fledged chicks. 


\section{Conclusions}

In other articles, the 30 previous years of the Refuge's history and 'possible future changes' were mentioned (Fernández 2004a, 2008c). In fact, the new situation poses many questions (Hernando et al. 2005, Ramos 2003). Moreover, new problems have appeared, and remain unsolved in spite of support given to the Refuge Fund by institutions such as "Defensor del Pueblo" and "Procurador del Común", and many other persons and organisations (see Fernández 2005c, 2008a; Gomis 2005, 2006). On the other hand, the Natural Park program and its managers should consider the knowledge acquired by many people over previous decades, who have conserved the Refuge and its wildlife (see González 2008, Molina 2008, Ruiz 2006).

The region is also affected by the present problems on the withdrawal of carcasses in Spain (Camiña 2004a; Camiña \& López 2009; González \& Moreno-Opo 2008), and by other general problems (Camiña 2004b; Terrasse 2006). An important review on the main threats for the Iberian vultures appears in the conclusions of the course "Jornadas sobre
Buitres" (UNED, Plasencia, 2007; see Raptor Research Foundation 2007), and of the national congress organised by Caralluma (Caravaca 2008; Fernández 2008b). The "III Jornadas sobre Buitres" were devoted to several important guards or naturalists (see Aguilera 2006; Camiña 2005, Fernández 2007d, Ravussin 2007).

The hunger of the vultures is barely relieved by the few vulture restaurants that continue to function. A total of 8,887 carcasses have been placed in the feeding site of WWF Spain between 1975 and the first three months of 2009: 5,412 pigs, 3,150 sheep, 99 horses, 79 cows, 24 roe deer, 21 dogs, 16 goats, 11 mules, 11 donkeys, 9 wild boars, one red deer, three cats, two turkeys, 48 hens, one duck, and incomplete remains of various animals. In this sense, the work of Jesús Hernando, Refuge guard of WWF Spain, is essential (Camiña 2005).

In the past, the censuses and works carried out in the Refuge have been very useful for knowing the trends in many other Spanish regions. The present situation, and range of threats described above, makes the new results of such studies especially important and interesting. 


\section{Acknowledgements}

For almost 35 years, I have had the kind and unselfish collaboration of more than 1,500 people, who have devoted part of their lives to the Refuge and its surroundings. A partial list of several hundred of them can be found in Fernández 1993a, 2006, 2007b. I really appreciate all the people who have made possible the survival of this wildlife Refuge, during its incredible history, in spite of the many difficulties and troubles.

I am also grateful to all those who continue working generously to conserve the scavenger birds and their world; especially the ornithologists and organisations who took part in the three "Jornadas sobre Buitres" (UNED), and the Caralluma Association who organised the national congress of 2008 in Caravaca (Murcia); and also, the Refuge Fund, the FAB ("Fondo Amigos del Buitre"), and the platform "Save the vultures". Two reviewers are thanked for comments on the article.

\section{References}

Aguilera Sanz, J. M. 2006. In memory of a great naturalist, David Gómez Samitier. Vulture News 54: 61-62.

Arroyo, B., Ferreiro, E. \& Garza, V. 1990. II Censo Nacional de Buitre Leonado (Gyps fulvus): población, distribución, demografía y conservación. ICONA. Colección Técnica. Madrid. 95 pp.

Arroyo, B., Ferreiro, E. \& Garza, V. 1996. El Águila Perdicera (Hieraaetus fasciatus) en España. Censo, reproducción y conservación. ICONA. Colección Técnica. Madrid. $86 \mathrm{pp}$.

Barrios Partida, F. 2007. Nómadas del Estrecho de Gibraltar / Nomads of the Strait of Gibraltar. Acento 2000. Cádiz. 432 pp.

Blanco Hervás, G., Martínez Olivas, F. \& Traverso Martínez, J. M. 1997. Pair bond and age distribution of breeding Griffon Vultures Gyps fulvus in relation to reproductive status and geographic area in Spain. Ibis 139: 180-183.

Camiña Cardenal, Á. 2003. Rüppell's Griffon observations in Spain. Vulture News 49: 23-24.

Camiña Cardenal, Á. 2004a. Consequences of Bovine Spongiform Encephalopathy (BSE) on breeding success and food availability in Spanish Vulture populations. Pp. 27-44 in: Chancellor, R. D. y Meyburg, B.-U. (eds.). Raptors Worldwide. Proceedings of the VI World Conference on Birds of Prey and Owls. WWGBP (World Working Group on Birds of Prey and Owls) \& MME/BirdLife Hungary. Budapest (Hungary), V-2003. 867 pp.

Camiña Cardenal, Á. 2004b. Griffon Vulture Gyps fulvus monitoring in Spain: current research and conservation projects. Pp. 45-66 in: Chancellor, R. D. y Meyburg, B.-U. (eds.). Raptors Worldwide. Proceedings of the VI World Conference on Birds of Prey 
and Owls. WWGBP (World Working Group on Birds of Prey and Owls) \& MME/ BirdLife Hungary. Budapest (Hungary), V-2003. 867 pp.

Camiña Cardenal, Á. 2005. Reflections of the Montejo Raptor Refuge's Hoticiano Hernando. Vulture News 52: 31-33.

Camiña Cardenal, Á. 2007. Muladares para el buitre leonado en el Sistema Ibérico. Quercus 261: 22-27.

Camiña Cardenal, Á. \& López Hernández, Ch. 2009. Los buitres en España. El Ecologista 60: 49-51.

Cobo Anula, J. 1992. Refugio de Rapaces de Montejo. ADENA/WWF y Unión Fenosa colaboran en el aislamiento de tendidos eléctricos peligrosos. Panda 38: 34-36.

Cobo Anula, J. \& Suárez Arangüena, L. 2000. Refugio de Rapaces de Montejo de la Vega (Segovia). 25 años conservando la naturaleza. Panda 69: 17-24.

De Juana Aranzana, E. 2006. Aves raras de España: un catálogo de las especies de presentación ocasional. Lynx Edicions, Barcelona, 480 pp.

De Juana Aranzana, E. \& Camiña Cardenal, Á. 2001. Observations of Rüppell's Griffon in Spain. Vulture News 44: 36-40.

De la Puente Nilsson, J. Moreno-Opo Díaz-Meco, R. \& Del Moral González, J. C. 2007. El buitre negro en España. Censo Nacional (2006). SEO/BirdLife, Seguimiento de Aves 13, Madrid, 113 pp.

Del Moral, J. C. \& Martí, R. (eds.). 2001. El Buitre Leonado en la Península Ibérica, III Censo Nacional y I Censo Ibérico coordinado, 1999. Monografía no. 7. SEO/BirdLife, Madrid, $140 \mathrm{pp}$.

Del Moral, J. C. \& Martí, R. (eds.). 2002. El Alimoche Común en España y Portugal (I Censo coordinado). Año 2000. Monografía no. 8. SEO/BirdLife, Madrid, 176 pp.

Doval de las Heras, G., Marchamalo de Blas, J., Suárez Arangüena, L., Melero de Blas, Ma \& Hernando Iglesias, J. 2005. Venenos y tendidos, causas principales de la mortalidad del alimoche en las hoces del Riaza. Quercus 237: 14-20.

FAB (2008). Vulture crisis in Aragón (North Spain). Unpublished report.

Fernández, C. Azkona, P. \& Donázar, J. A. 1998. Density-dependent effects on productivity in the Griffon Vulture Gyps fulvus: the role of interference and habitat heterogeneity. Ibis 140: 64-69.

Fernández y Fernández-Arroyo, F. J. 1976. Sobre el Refugio de Rapaces de Montejo. ADENA 12: 17-22.

Fernández y Fernández-Arroyo, F. J. 1981. Resumen del censo de Buitres Leonados (Gyps fulvus) en el Refugio de Rapaces de Montejo y en sus inmediaciones. Ardeola 26-27: 249-250. 
Fernández y Fernández-Arroyo, F. J. 1983. Apuntes sobre el Refugio de Rapaces de Montejo. Quercus 9: 19-20.

Fernández y Fernández-Arroyo, F. J. 1984. Novedades sobre el Refugio de Rapaces de Montejo. Quercus 13: 41.

Fernández y Fernández-Arroyo, F. J. 1993a. Lista de vertebrados del Refugio de Rapaces de Montejo (1975-1992). Publ. by the autor, Madrid. 55 pp.

Fernández y Fernández-Arroyo, F. J. 1993b. Impacto humano en las poblaciones de rapaces rupicolas. Publ. by the author. Madrid. $39 \mathrm{pp}$.

Fernández y Fernández-Arroyo, F. J. 1994a. Common Ravens nesting beside Griffon Vultures. British Birds 87 (1): 42.

Fernández y Fernández-Arroyo, F. J. 1994b. El alimoche en el Refugio de Rapaces de Montejo. Biblioteca, estudio e investigación 9: 135-182.

Fernández y Fernández-Arroyo, F. J. 1996a. Sobre los censos realizados en el Refugio de Rapaces de Montejo (1975-1994). In: Muntaner, J. \& Mayol, J. (Eds.). Biología y Conservación de las Rapaces Mediterráneas, 1994; pp. 317-321. Monografías no 4. SEO/BirdLife. Madrid. 488 pp.

Fernández y Fernández-Arroyo, F. J. 1996b. Los mamiferos del Refugio de Rapaces de Montejo. Publ. by the author, Madrid. $62 \mathrm{pp}$.

Fernández y Fernández-Arroyo, F. J. 1997. Los censos de rapaces en el Refugio de Montejo. Bolegyps 3: 6-11.

Fernández y Fernández-Arroyo, F. J. 1998a. El águila perdicera en el Refugio de Rapaces de Montejo. Publ. by the author, Madrid. 26 pp.

Fernández y Fernández-Arroyo, F. J. 1998b. Observaciones de buitres africanos en España. 100cias@uned 1: 32-40.

Fernández y Fernández-Arroyo, F. J. 1998c. Sobre buitres leonados y negros en el Refugio de Rapaces de Montejo. Bolegyps 4: 5-11.

Fernández y Fernández-Arroyo, F. J. 1999. Vulture populations in the Montejo Raptor Refuge, Spain. Vulture News 40: 3-19.

Fernández y Fernández-Arroyo, F. J. 2001a. Exceptional behaviour of an Eurasian Griffon Gyps fulvus chick. Vulture News, 45: 26-28.

Fernández y Fernández-Arroyo, F. J. 2001b. The Montejo Raptor Refuge (1975-2001). In: Abstracts of the $4^{\text {th }}$ Eurasian Congress on Raptors, pp. 62-63. Estación Biológica de Doñana \& Raptor Research Foundation. Sevilla, Spain.

Fernández y Fernández-Arroyo, F. J. 2002. Hoja Informativa sobre el Refugio de Rapaces de Montejo no. 25, 112 pp.

Fernández y Fernández-Arroyo, F. J. 2003a. La protección de las hoces del Riaza será insuficiente. Letter. Quercus 208:4. 
Fernández y Fernández-Arroyo, F. J. 2003b. Las aves esteparias del Refugio de Rapaces de Montejo. Oxyura 11 (1): 167-179.

Fernández y Fernández-Arroyo, F. J. 2003c. New publications about the Montejo Raptor Refuge. Vulture News 49: 53.

Fernández y Fernández-Arroyo, F. J. 2004a. Recent vulture censuses in the Montejo Raptor Refuge, Spain. Vulture News 51: 46-53.

Fernández y Fernández-Arroyo, F. J. 2004b. Hoja Informativa sobre el Refugio de Rapaces de Montejo no. 27, 220 pp.

Fernández y Fernández-Arroyo, F. J. 2005a. News about the Montejo Raptor Refuge (Spain). Wingspan 14 (2): 6.

Fernández y Fernández-Arroyo, F. J. 2005b. Más noticias sobre buitres africanos en España. In: Actas del III Congreso Internacional sobre Aves Carroñeras, pp. 23-24. Ecologistas en Acción. Ed. Diputación Provincial de Guadalajara. 126 pp.

Fernández y Fernández-Arroyo, F. J. 2005c. Dudoso futuro para las hoces del Riaza. Quercus 229: 82.

Fernández y Fernández-Arroyo, F. J. 2006. Hoja Informativa sobre el Refugio de Rapaces de Montejo no. 29, 230 pp.

Fernández y Fernández-Arroyo, F. J. 2007a. Censando y protegiendo buitres. In: Gómez Samitier, D. \& 91 collaborators. Uñas de cristal, pp. 126-133. Ed. Prames. Zaragoza, $352 \mathrm{pp}$.

Fernández y Fernández-Arroyo, F. J. 2007b. Hoja Informativa sobre el Refugio de Rapaces de Montejo no. 31, 314 pp.

Fernández y Fernández-Arroyo, F. J. 2007c. Bajón en el censo de pollos de buitre leonado de las hoces del Riaza. / Preocupación en la reunión de expertos de Plasencia. Quercus 261: 33-34.

Fernández y Fernández-Arroyo, F. J. 2007d. Señales de alarma sobre la situación de los buitres. / Conclusiones de las III Jornadas sobre Buitres. Argutorio 20: 29-31.

Fernández y Fernández-Arroyo, F. J. 2008a. Hoces del Riaza: el Refugio de Rapaces cumple 33 años. Guardabosques 40: 38-39.

Fernández y Fernández-Arroyo, F. J. 2008b. Hoja Informativa sobre el Refugio de Rapaces de Montejo no. 32, 360 pp.

Fernández y Fernández-Arroyo, F. J. 2008c. Breve reseña sobre la historia del Refugio de Rapaces de Montejo. In: La Leyenda de las cárcavas. / Crónicas de naturalistas españoles en el Refugio de Rapaces de Montejo de la Vega (Segovia), pp. 39-68. Ed. Universa Terra. Salamanca, 252 pp.

Fernández y Fernández-Arroyo, F. J. 2009. Declive de buitres en las hoces del Riaza. Letter. Quercus 275: 4. 
Forsman, D. 2005. Rüppell's Vultures in Spain. Birding World 18 (10): 435-438.

Gomis Martín, E. 2005. Medidas positivas en la polémica senda de las hoces del Riaza. Letter. Quercus 238: 4.

Gomis Martín, E. 2006. Informe del Defensor del Pueblo en contra de la Senda Larga. Letter. Quercus 249: 5.

González, L. M., \& Moreno-Opo Díaz-Meco, R. 2008. Impacto de la falta de alimento en las aves necrófagas amenazadas. Ambienta 73: 48-55.

González Rodríguez, R. 2008. Historia de un emblemático lugar: las Hoces del Riaza. In: La Leyenda de las cárcavas. / Crónicas de naturalistas españoles en el Refugio de Rapaces de Montejo de la Vega (Segovia), pp. 9-19. Ed. Universa Terra. Salamanca, 252 pp.

Griesinger, J. 1996. Autumn migration fo Griffon Vultures (Gyps f. fulvus) in Spain. In: Muntaner, J. \& Mayol, J. (Eds.). Biología y Conservación de las Rapaces Mediterráneas, 1994; pp. 401-410. Monografías no 4. SEO/BirdLife. Madrid. 488 pp.

Griesinger, J. 1998. Juvenile dispersion and migration among Griffon Vultures Gyps fulvus in Spain. Pp. 613-621 In: Chancellor, R. D.; Meyburg, B.-U. \& Ferrero, J. J. (Eds.). Holartic Birds of Prey; pp. 613-621. ADENEX-WWGBP, Badajoz. 680 pp.

Gutiérrez, R. 2003. Occurrence of Rüppell's Griffon Vulture in Europe. Dutch Birding 25: 289-303.

Hernández Segovia, M., \& Margalida Vaca, A. 2009. Poison-related mortality effects in the endangered Egyptian vulture (Neophron percnopterus) population in Spain. European Journal of Wildlife Research, 55.

Hernando Iglesias, J., Melero de Blas, Mª \& Suárez Arangüena, L. 2005. Refugio de Montejo: tres décadas conservando la naturaleza. Quercus 237: 10-13.

Linares Tello, C. 2008. Sensibilización en Montejo. / El Refugio más cerca de todos. / Carroñeras en las Hoces del Riaza. Panda, 104:34.

López Laguna, F. Guarda de Montejo por un verano. Panda 29: 31-34.

LPO, 2008. Les vautours: Alliés indispensables et fragiles du pastoralisme. 14 pp. Ligue pour la Protection des Oiseaux.

Martínez Olivas, F. 1985. Éxito reproductor del Buitre Leonado en Montejo de la Vega. Panda 12: 16-17.

Martínez Olivas, F. \& Blanco Hervás, G. 2002. Use of alternative nests for clutch replacement in the Egyptian Vulture Neophron percnopterus. Ardeola 49 (2): 297-299.

Martínez Olivas, F., Blanco Hervás, G. \& Rodríguez Manzano, R. F. 1998. Rate, timing and success of clutch replacement by colonial Griffon Vultures Gyps fulvus. Ornis Fennica 75: 145-148.

Martínez Olivas, F. \& Cobo Anula, J. 1993. Gestión actual de ADENA/WWF España en el Refugio de Rapaces de Montejo de la Vega (Segovia). Alytes 6: 507-521. 
Martínez Olivas, F. \& Fernández y Fernández-Arroyo, F. J. 1992. Predación de huevos o pollos de buitres leonados. Boleta 5: 2.

Martínez Olivas, F., Rodríguez Manzano, R, F. \& Blanco Hervás, G. 1997. Effects of monitoring frequency on estimates of abundance, age distribution, and productivity of colonial Griffon Vultures. Journal of Field Ornithology 68 (3): 329-399.

Melero de Blas, $\mathrm{M}^{\mathrm{a}}$. 2005. ¿Un punto negro eliminado? / Modificación del tendido eléctrico de Campo de San Pedro. Panda 88: 26.

Melero de Blas, $\mathrm{M}^{\mathrm{a}}$. 2006a. Vivero escolar. Panda 93: 27.

Melero de Blas, $\mathrm{M}^{\mathrm{a}}$ 2006b. El 2006 avanza... y la actividad en el Refugio se intensifica. Panda 94: 30.

Melero de Blas, Ma . 2007a. Madurez con preocupación. / Hace ya 32 años que se declaró el Refugio de Montejo. Panda 97: 35.

Melero de Blas, $M^{a}$. 2007b. Respiro para las carroñeras. Nuevo Real Decreto para la alimentación de aves rapaces en muladares. Panda 99: 20-22.

Melero de Blas, Ma. \& Suárez Arangüena, L. 2005. 30 años de armonía en el Refugio. / Se cumple el $30^{\circ}$ aniversario del Refugio de Rapaces de Montejo de la Vega. Panda 89: 8-13.

Melero de Blas, $\mathrm{M}^{\mathrm{a}}$., Suárez Arangüena, L., y Hernando Iglesias, J. 2007. Tres años de la remodelación del tendido de Campo de San Pedro. Bolegyps 44: 2.

Melero de Blas, Ma., Suárez Arangüena, L. \& Hernando Iglesias, J. 2008. Resultados de la reproducción de Buitre Leonado. Bolegyps 45: 2

Molina Pérez, J. J. 2008. El Refugio de Montejo y yo. Sufrimientos y alegrías. In: La Leyenda de las cárcavas. / Crónicas de naturalistas españoles en el Refugio de Rapaces de Montejo de la Vega (Segovia), pp. 209-213. Ed. Universa Terra. Salamanca, 252 pp. Moreno-Opo, R. \& Guil, F. (coords.) 2007. Manual de gestión del hábitat y de las poblaciones de buitre negro en España. Dirección General para la Biodiversidad, Ministerio de Medio Ambiente, Madrid, 404 pp.

Perea Rodríguez, J.L., Morales Villarroel, M. \& Velasco Cabas, J. 1990. El Alimoche (Neophron percnopterus) en España. Población, distribución, problemática y conservación. ICONA. Colección Técnica. Madrid. 63 pp.

Pérez de Ana, J. M. 2007. Los buitres de Sierra Salvada sufren la recogida de ganado muerto. Quercus 261: 30-32.

Prieto Martín, J. (coord.), Armendáriz Sanz, J. L. \& Fernández y Fernández-Arroyo, F. J. 2007. Informe final del XXIV Censo de vertebrados realizado los días 11 y 12 de noviembre de 2006, en las Hoces del río Riaza (Refugios de Rapaces de Montejo y de Linares del Arroyo, resto del Parque Natural, e inmediaciones) y en peñas y barrancos próximos. $89 \mathrm{pp}$. 
Prieto Martín, J. (coord.), Armendáriz Sanz, J. L. \& Fernández y Fernández-Arroyo, F. J. 2008. Informe final del XXV Censo de vertebrados realizado los días 10 y 11 de noviembre de 2007, en las Hoces del río Riaza (Refugios de Rapaces de Montejo y de Linares del Arroyo, resto del Parque Natural, e inmediaciones) y en peñas y barrancos próximos. $108 \mathrm{pp}$.

Ramos Sánchez, R. 2003. Sombras, y no de buitres, planean sobre Montejo. Letter. Quercus 211: 6.

Raptor Research Foundation. 2007. Conclusions of the III Symposium on Vultures. / Summer Course of the UNED -Spanish Open University- / Plasencia (Cáceres) / 9-3 July 2007. (Translated by Claire Graham, and submitted by Dr. Fidel José Fernández y Fernández-Arroyo). Wingspan, 16 (2): 12-14.

Ravussin, P.-A. 2007. In memoriam. Daniel Magnenat (1927-2007). Nos Oiseaux, 54 (3) (489): 189-190.

Razin, M., Rebours, I. \& Arthur, C. 2008. Le Vautour fauve Gyps fulvus dans les Pyrénées françaises: status récent et tendance. Ornithos 5-6: 385-393.

Ruiz Heredia, A. 2006. Comentarios sobre un artículo aparecido en la revista Bolecín. El Nordeste de Segovia 67: 5.

Ruiz-Olmo, J. \& Delibes de Casto, M. 1999. La nutria en España ante el horizonte del año 2000. SECEM. 300 pp.

Suárez Arangüena, L. 2000. Refugio de Rapaces de Montejo. Panda, 70: 32.

Suárez Arangüena, L. 2007. Envenenamiento masivo cercano a las hoces segovianas del río Riaza. Quercus 255: 78-79.

Suárez Arangüena, L. 2008. Buitres hambrientos. Panda 102: 23.

Tella Escobedo, J. L. 2006. Action is needed now, or BSE crisis could wipe out endangered birds of prey. Vulture News 55: 35-36.

Terrasse, M. 2006. Évolution des déplacements du Vautour fauve Gyps fulvus en France et en Europe. Ornithos 13-5: 273-299.

WWF/Adena. 2007. Víctimas de un tendido ya corregido. Quercus 251: 66.

Zuberogoitia Arroyo, Í. 2009. Molestias a los alimoches norteños. Quercus 277: 14-19.

\section{a}




\section{Appendix 1 - Graphics of population trends}

Figure 1. Number of Griffon vultures in the autumn censuses.

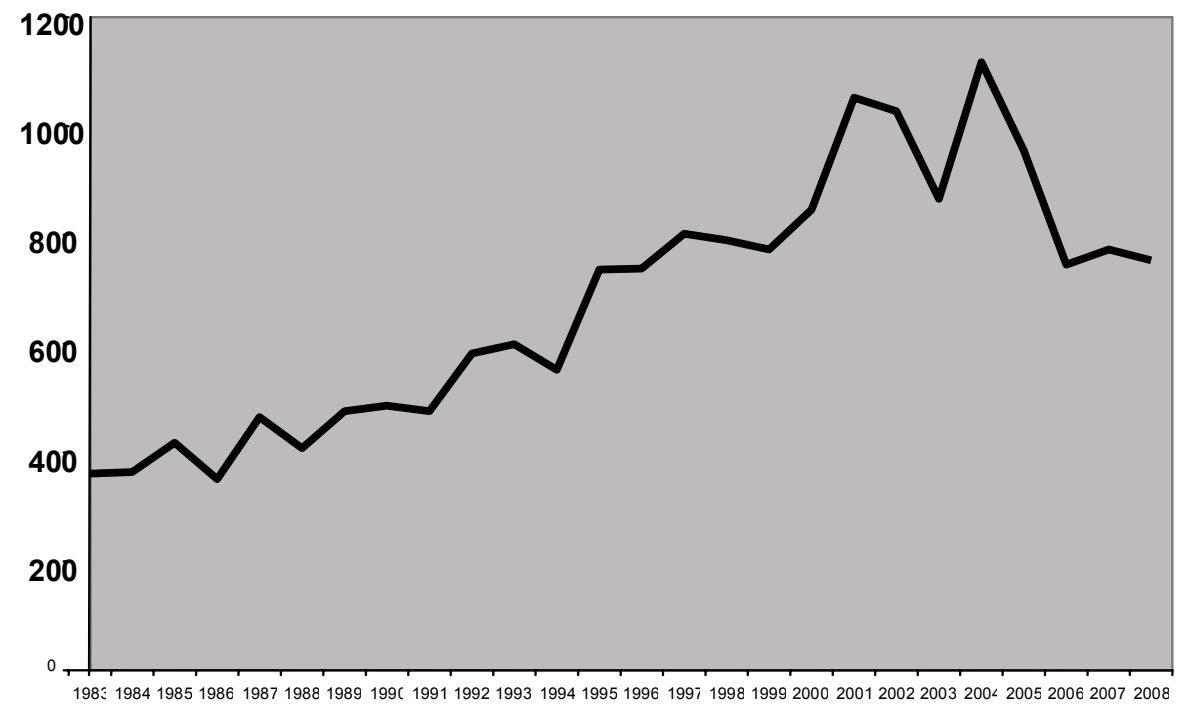

Figure 2. Number of fledgling chicks of Griffon vultures, in the Riaza gorges and in the surroundings.

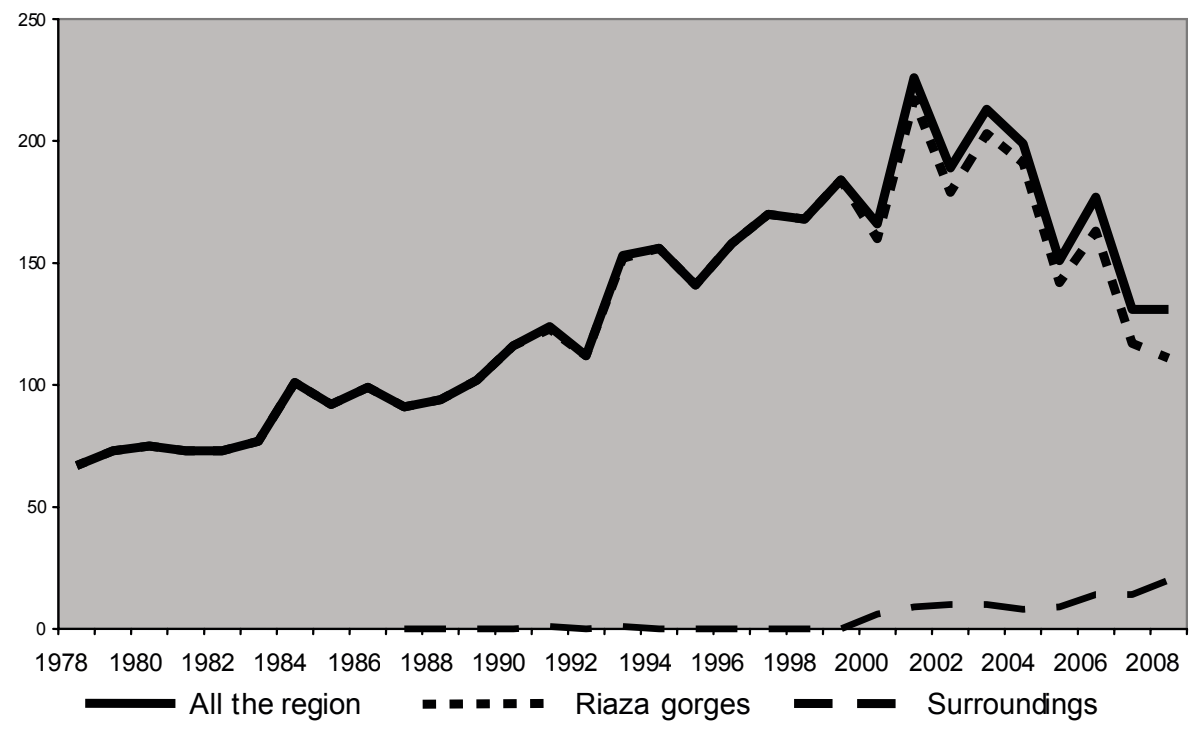


Figure 3. Number of pairs of Egyptian vultures, in the Riaza gorges and in the surroundings.

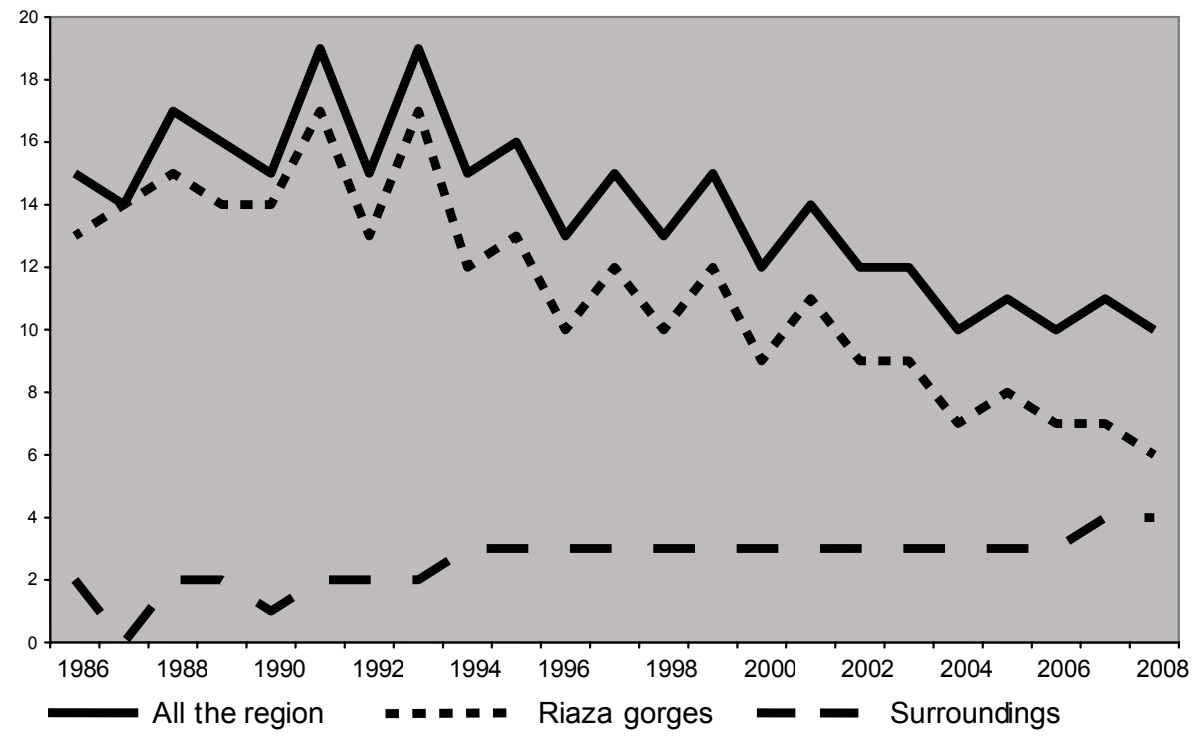

Figure 4. Number of fledgling chicks of Egyptian vultures, in the Riaza gorges and in the surroundings.

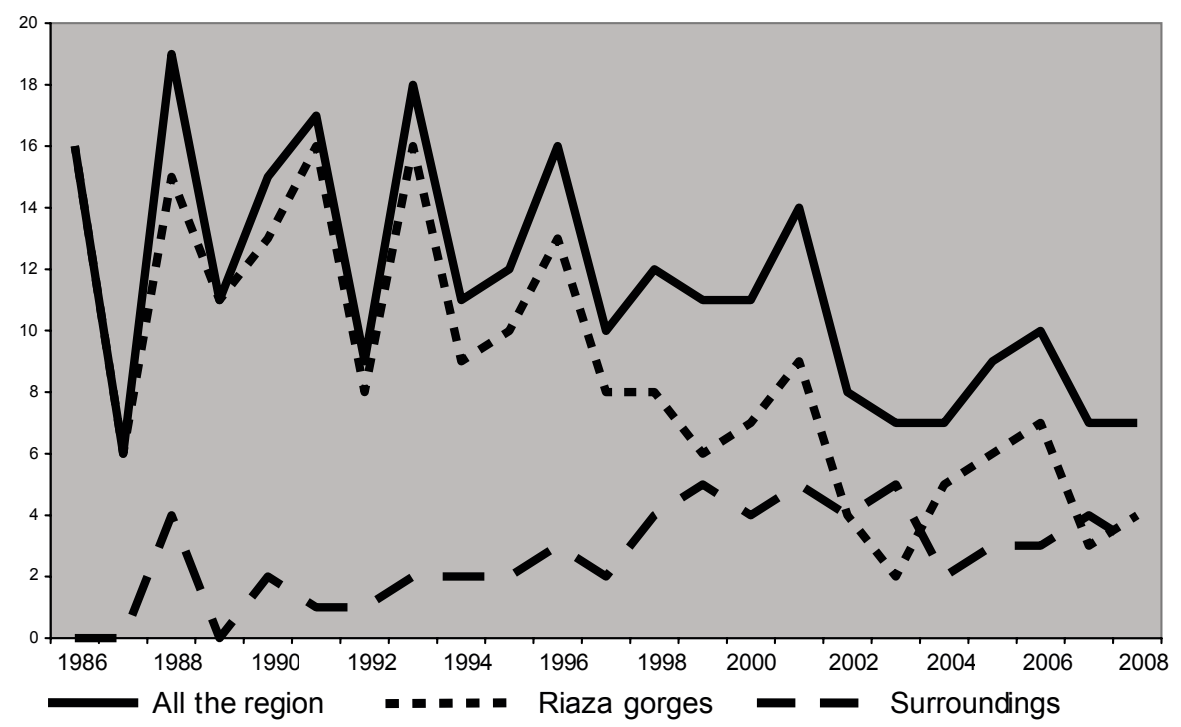

